\title{
PENGARUH PENGGUNAAN MEDIA AUDIO VISUAL DALAM PEMBELAJARAN PROBLEM POSING TERHADAP MOTIVASI DAN HASIL BELAJAR LARUTAN PENYANGGA
}

\author{
Sukma Rosyida ${ }^{\mathrm{a}}$, Munzil ${ }^{\mathrm{b}}$, Ridwan Joharmawan ${ }^{\mathrm{c} 1}$ \\ a,b,c Jurusan Kimia FMIPA Universitas Negeri Malang
}

\begin{abstract}
Abstrak - Penelitian ini bertujuan untuk mengetahui perbedaan motivasi belajar dan hasil belajar kognitif antara siswa yang dibelajarkan menggunakan media audio visual pada pembelajaran materi larutan penyangga dengan strategi Problem Posing dengan siswa yang dibelajarkan dengan strategi Problem Posing tanpa menggunakan media audio visual pada pembelajaran materi larutan penyangga. Rancangan penelitian yang digunakan adalah rancangan penelitian eksperimental semu (quasy experimental design). Populasi penelitian adalah siswa kelas XI MAN 2 Kota Batu. Sampel adalah siswa kelas XI IPA 3 dan XI IPA 4 yang ditentukan secara purposive random sampling dengan nilai signifikansi 0,22. Data motivasi belajar siswa diperoleh dari angket motivasi belajar sedangkan data hasil belajar siswa didapat melalui tes yang dilakukan di akhir proses pembelajaran. Analisis data motivasi belajar dan hasil belajar dilakukan menggunakan uji-U Mann Whitney dengan bantuan program SPSS 21.0 for Windows. Berdasarkan hasil penelitian, diperoleh hasil bahwa (1) terdapat perbedaan motivasi belajar siswa yang dibelajarkan dengan strategi Problem Posing menggunakan media audio visual pada materi larutan penyangga. Siswa yang dibelajarkan dengan strategi Problem Posing menggunakan media audio visual memperoleh rata-rata motivasi belajar sebesar 79,84 (kriteria termotivasi) lebih tinggi dibanding siswa yang dibelajarkan dengan Problem Posing tanpa menggunakan media audio visual dengan rata-rata motivasi belajar sebesar 72,63 (kriteria termotivasi); (2) terdapat perbedaan hasil belajar kognitif antara siswa yang dibelajarkan dengan Problem Posing menggunakan media audio visual dengan rata-rata hasil belajar kognitif sebesar 74,25 (kriteria cukup), lebih tinggi dibandingkan dengan rata-rata hasil belajar siswa yang dibelajarkan dengan Problem Posing tanpa menggunakan media audio visual yaitu 58,60 (kriteria kurang).
\end{abstract}

\section{Kata kunci: Media audio visual, Problem posing, Motivasi belajar, Hasil belajar kognitif, Larutan} penyangga

\begin{abstract}
The aim of this research were to know the difference of learning motivation and cognitive learning outcomes between students who has been learned by using audio visual media with Problem Posing strategy and students who has been learned without audio visual media on buffer solution. The design used in this research was quasy experimental. The research population was students of XI grade in MAN 2 Kota Batu. The samples were XI IPA 3 and XI IPA 4. The samples were determined by using purposive random sampling which had
\end{abstract}

\footnotetext{
${ }^{1}$ Corresponding authors: Ridwan Joharmawan, Program Studi Pendidikan Kimia, Universitas Negeri Malang, Malang 65145, Indonesia. Email: ridwan.joharmawan.fmipa@um.ac.id
}

ISSN: 2528-6536 (cetak)/ISSN: 2579-5945 (online)

(a)2017 J-PEK 
0,22 significant value. The data of student's learning motivation was obtained from motivation questionnaire whereas the data of learning outcomes was obtained from cognitive tests ability. The data of learning outcomes and learning motivation were analyzed by Mann Whitney U-test with SPSS 21.0 for Windows. Based on the research, the result are (1) There was difference motivation's score between students who has been learned by using audio visual media with Problem Posing strategy and students who has been learned without audio visual media. Students who has been learned by using audio visual media had the average score of 79.84 ("motivated" criteria), higher than students who has been learned without audio visual media which had 72,63 average score ("motivated" criteria). (2) There was difference student cognitive learning outcome who has been learned by using audio visual media with Problem Posing strategy and students who has been learned without audio visual media. Students who has been learned without audio visual had the average score of 58.60 ("bad" criteria), lower than the students who has been learned by using audio-visual media which had 74.25 average score ("good enough" criteria).

Keywords: Audio visual media, Problem posing, Learning motivation, Cognitive Learning Outcomes, Buffer Solution

\section{PENDAHULUAN}

Pembelajaran larutan penyangga diberikan kepada siswa kelas XI IPA Semester II. Selama kegiatan pembelajaran, seringkali siswa mengalami kesulitan dalam memahami materi larutan penyangga. Hal ini didukung oleh penelitian yang diadakan pada tahun 2011 yakni Amarta yang telah melakukan penelitian mengenai kesalahan konsep yang terjadi pada siswa kelas XI SMAN 1 Tumpang tahun pelajaran 2010/2011. Sampel penelitian adalah siswa kelas XI IPA 1 dan XI IPA 3. Hasil penelitian menunjukkan bahwa siswa mengalami kesalahan konsep pada subbab komponen larutan penyangga dengan persentase 24,90\%, kesalahan konsep pada cara kerja larutan penyangga sebesar 36,67\%, kesalahan konsep pada subbab penentuan $\mathrm{pH}$ larutan penyangga sebesar 34,34\%, kesalahan konsep pada subbab fungsi larutan penyangga sebesar 29,25\%, dan kesalahan konsep pada materi larutan penyangga secara keseluruhan sebesar 31,29\%. Hal tersebut menunjukkan bahwa rata-rata siswa mengalami kesulitan dalam memahami konsep larutan penyangga.

Kesalahan konsep yang terjadi pada siswa kemungkinan disebabkan karena penggunaan metode belajar yang hanya berpusat pada guru (teacher centered), seperti ceramah atau mendikte, yang membuat siswa kurang memiliki kesempatan untuk mengkonstruk dan mengeksplor pengetahuan secara lebih luas. Hal tersebut mengakibatkan retensi dan pemahaman siswa mengenai materi larutan penyangga rendah. Oleh sebab itu, kesalahan-kesalahan konsep di atas perlu diatasi karena dapat mempengaruhi hasil belajar siswa. Salah satu cara yang digunakan adalah dengan menggunakan strategi pembelajaran yang dapat membantu siswa dalam memahami materi larutan penyangga (Sagala, 2003:174).

Berdasarkan kharakteristik materinya, strategi pembelajaran yang dapat digunakan adalah Problem Posing. Problem Posing memiliki prinsip dapat melakukan penyusunan dan penyelesaian soal (Iskandar, 2011). Siswa yang dibelajarkan dengan membentuk soal akan memiliki kesempatan untuk mengeksplor materi secara lebih luas dan mandiri. Hal tersebut sangat baik bagi siswa dalam mengkonstruk pengetahuannya tentang materi 
larutan penyangga. Selain itu bila dilihat dari karakteristik materi larutan penyangga yang terdapat hitungan atau operasi matematik dan membutuhkan pemahaman siswa dalam aspek simbolik membuat strategi pembelajaran Problem Posing baik untuk digunakan. Penelitian yang dilakukan Akay dan Boz (2010) mengenai penerapan Problem Posing terhadap pengajaran dan pembelajaran matematika menunjukkan hasil yang positif dan signifikan. Selanjutnya Silver \& Cai (1993) dalam El Sayed (2000) menemukan hubungan positif yang sangat kuat antara kemampuan membentuk soal dengan kemampuan menyelesaikan masalah. Melalui pembelajaran Problem Posing siswa diharapkan mampu berpikir kritis dan kreatif serta mampu menjadi "problem solver" yang baik. Bahkan Silver (1990) dalam Akay \& Boz (2010) menjelaskan bahwa dengan Problem Posing, guru dapat memahami proses kognitif siswa lebih baik, menemukan kemungkinan terjadi miskonsepsi di awal proses pembelajaran dan mendapat informasi tentang level pencapaian siswa.

Keefektifan pembelajaran Problem Posing bertambah apabila dikolaborasikan dengan bantuan lain agar hasilnya lebih maksimal. Salah satunya dengan memanfaatkan peran media audio visual dalam membantu siswa menerima dan memahami materi larutan penyangga sebagai pengetahuan awal. Dengan menggunakan media audio visual, aspek makroskopik, mikroskopik, dan simbolik dapat disajikan secara bersama. Kozma \& Russell (1997) dalam Pekdag (2010) menjelaskan bahwa pengetahuan konseptual dalam kimia berkaitan dengan kemampuan untuk menjelaskan fenomena kimia dari aspek makroskopik, mikroskopik, dan simbolik. Ketiga aspek tersebut harus disatukan dalam memahami materi larutan penyangga. Media audio visual yang tepat dapat membantu siswa dalam memahami konsep materi larutan penyangga. Penggunaan media audio visual dalam pembelajaran materi larutan penyangga dirasa tepat karena metode pembelajaran yang sering digunakan adalah metode konvensional. Padahal fasilitas berupa LCD dan screen sudah tersedia di masing-masing kelas di MAN 2 Kota Batu namun jarang sekali siswa dieksplor untuk menggunakan teknologi yang ada ketika proses pembelajaran.

Penggunaan media audio visual pada pembelajaran Problem Posing memberikan kesempatan lebih luas bagi siswa untuk mengkonstruk pengetahuannya secara utuh dari aspek makroskopik, mikroskopik, dan simbolik. Diharapkan pemahaman siswa akan materi larutan penyangga tinggi dan hasil belajar siswa pun akan lebih baik daripada sekedar diceramahi atau didikte. Selain itu, dengan bantuan media audio visual diharapkan mampu meningkatkan motivasi belajar siswa. Salah satu saran Santrock (2008) dalam menarik perhatian anak dalam pembelajaran di kelas adalah membuat pembelajaran menjadi menarik dan menggunkan media dan teknologi dengan efektif. Media audio visual yang digunakan adalah media audio visual larutan penyangga yang telah dikembangkan oleh Yuniar Wijayanti Wikator pada tahun 2012.

\section{METODE}

Penelitian ini menggunakan desain penelitian eksperimen semu. Skema rancangan penelitian disajikan dalam Tabel 1. 
Tabel 1. Rancangan penelitian

\begin{tabular}{ccccc}
\hline Subjek & Pretest & Perlakuan & Posttest & Angket motivasi \\
\hline $\mathrm{E}$ & - & $\mathrm{X} 1$ & $\mathrm{O} 1$ & O2 \\
$\mathrm{K}$ & - & $\mathrm{X} 2$ & O3 & O4 \\
\hline
\end{tabular}

Keterangan :

$\mathrm{E} \quad=$ kelas eksperimen

$\mathrm{K}=$ kelas kontrol

$\mathrm{O} 1=$ postes atau tes setelah perlakuan pada kelas eksperimen

$\mathrm{O}_{2}=$ angket motivasi belajar siswa kelas eksperimen

$\mathrm{O} 3$ = postes atau tes setelah perlakuan pada kelas kontrol

$\mathrm{O}_{4}=$ angket motivasi belajar siswa kelas kontrol

$\mathrm{X}_{1}=$ pembelajaran dengan media audio visual dengan startegi Problem Posing

$\mathrm{X}_{2}=$ pembelajaran dengan strategi Problem Posing

Kemampuan awal siswa pada masing-masing kelas dilihat dari nilai Ulangan Tengah Semester (UTS) 2 siswa. Untuk mengetahui ada atau tidaknya perbedaan kemampuan awal siswa pada kelas kontrol dan kelas eksperimen maka dilakukan uji kesamaan dua rata-rata yang terlebih dahulu dilakukan uji prasyarat analisis, meliputi uji normalitas dan uji homogenitas.

Data motivasi belajar siswa didapat melalui angket yang diberikan kepada siswa di akhir penelitian. Langkah-langkah analisis angket motivasi belajar siswa meliputi: a) memberi skor pada setiap pernyataan pada angket, b) menetapkan skor maksimum dan minimum yang mungkin diperoleh siswa., c) mengubah skor total yang diperoleh masingmasing siswa ke dalam skor 100, d) menentukan kriteria motivasi belajar siswa, e) menentukan kualifikasi motivasi belajar masing-masing siswa berdasarkan skor total dan kriteria yang telah ditetapkan, f) menentukan persentase kriteria motivasi belajar siswa. Data motivasi belajar dianalisis untuk menguji hipotesis.

Data hasil belajar siswa didapat melalui tes yang dilakukan setelah semua materi tersampaikan. Data hasil belajar dianalisis untuk menguji hipotesis. Sebelum dilakukan uji hipotesis dilakukan uji prasyarat analisis, meliputi uji normalitas dan uji homogenitas. Uji prasyarat analisis, uji kesamaan dua rata-rata, dan uji hipotesis, dilakukan dengan bantuan program SPSS 21.0 for windows.

\section{HASIL DAN PEMBAHASAN}

\section{HASIL}

\section{A. Deskripsi dan Analisis Data Kemampuan Awal Siswa}

Data kemampuan awal siswa diperoleh dari nilai Ulangan Tengah Semester (UTS) 2. Ringkasan data kemampuan awal siswa kelas kontrol dan kelas eksperimen dapat dilihat pada Tabel 2.

Tabel 2. Ringkasan Data Kemampuan Awal Siswa Kelas Ekperimen dan Kelas Kontrol

\begin{tabular}{lcccc}
\hline \multicolumn{1}{c}{ Kelas } & Jumlah Siswa & Nilai Terendah & Nilai Tertinggi & Rata-rata \\
\hline Eksperimen & 32 & 45,00 & 80,00 & 61,34 \\
Kontrol & 33 & 40,00 & 83,00 & 59,03 \\
\hline
\end{tabular}


Untuk mengetahui signifikansi perbedaan kemampuan awal siswa pada kelas kontrol dan kelas eksperimen, maka dilakukan uji kesamaan dua rata-rata terhadap data kemampuan awal siswa pada kedua kelas. Sebelum dilakukan uji kesamaan dua ratarata, terlebih dahulu dilakukan uji prasyarat analisis yang meliputi uji normalitas dan uji homogenitas.

Dari hasil uji normalitas Kolmogorov-smirnov dengan bantuan program SPSS 21.0 for Windows memperlihatkan bahwa data kemampuan awal siswa kelas eksperimen memiliki nilai signifikansi 0,20 yaitu lebih besar dari 0,05 sehingga dapat dikatakan bahwa data kemampuan awal siswa kelas eksperimen terdistribusi normal. Sedangkan kelas kontrol memiliki nilai signifikansi $<0,05$ yaitu 0,02 sehingga dapat dikatakan bahwa data kemampuan awal siswa kelas kontrol tidak terdistribusi normal.

Uji homogenitas dilakukan dengan bantuan program SPSS 21.0 for Windows dengan test Levene Statistic didapat nilai signifikansi sebesar $0,91 \quad(>0,05)$ sehingga disimpulkan bahwa kemampuan awal siswa kelas eksperimen dan kelas kontrol memiliki varian yang sama atau homogen sehingga kedua kelas dapat dijadikan subjek penelitian.

Data kemampuan awal siswa diuji kesamaan rata-rata dengan uji Mann-Whitney dengan bantuan SPSS 21.0 for Windows diperoleh nilai signifikansi 0,22 $(>0,05)$. Dapat disimpulkan bahwa tidak ada perbedaan kemampuan awal siswa kelas eksperimen dengan kelas kontrol.

\section{B. Deskripsi dan Analisis Motivasi Belajar Siswa}

Ringkasan data hasil motivasi belajar siswa dapat dilihat pada Tabel 3.

Tabel 3. Ringkasan Hasil Motivasi Belajar Siswa

\begin{tabular}{lccccc}
\hline & $\begin{array}{c}\text { Jumlah } \\
\text { siswa }\end{array}$ & Skor terendah & Skor tertinggi & Rata-rata & Kriteria \\
\hline Eksperimen & 32 & 66,00 & 97,00 & 79,84 & Termotivasi \\
Kontrol & 33 & 47,00 & 91,00 & 72,63 & Termotivasi \\
\hline
\end{tabular}

Persentase motivasi belajar siswa pada kelas eksperimen dan kelas kontrol disajikan dalam Tabel 4.

Tabel 4. Presentase Motivasi Belajar Siswa

\begin{tabular}{ccccc}
\hline & \multirow{2}{*}{ Sangat termotivasi } & $\begin{array}{c}\text { Termotivas } \\
\text { i }\end{array}$ & Tidak termotivasi & Sangat tidak termotivasi \\
\hline Eksperimen & $28,12 \%$ & $71,87 \%$ & $0,00 \%$ & $0,00 \%$ \\
Kontrol & $48,48 \%$ & $33,33 \%$ & $18,18 \%$ & $0,00 \%$ \\
\hline
\end{tabular}

Sebelum dilakukan uji hipotesis, dilakukan uji prasyarat analisis yang meliputi uji normalitas dan uji homogenitas. Hasil uji normalitas dilakukan menggunakan uji Kolmogorov-smirnov dengan bantuan program SPSS 21.0 for windows diperoleh nilai signifikansi 0,20 $(>0,05)$ untuk kelas eksperimen dan 0,001 $(<0,05)$ untuk kelas kontrol. Dengan demikian dapat disimpulkan bahwa data motivasi belajar siswa tidak terdistribusi 
normal. Uji homogenitas dengan bantuan program SPSS 21.0 for windows dengan Test of Homogenity of Variance (Levene) dan diperoleh nilai signifikansi 0,05 (>0,05). Dapat disimpulkan bahwa data motivasi belajar siswa kelas kontrol dan kelas eksperimen memiliki varian yang sama/ homogen.

\section{Deskripsi dan Analisis Data Hasil Belajar Siswa}

Ringkasan data hasil belajar siswa disajikan di dalam Tabel 5.

Tabel 5. Ringkasan Data Hasil Belajar Siswa

\begin{tabular}{lcccc}
\hline \multicolumn{1}{c}{ Kelas } & Jumlah Siswa & Nilai Terendah & Nilai Tertinggi & Rata-rata \\
\hline Eksperimen & 32 & 52,00 & 88,00 & 74,25 \\
Kontrol & 33 & 24,00 & 76,00 & 58,61 \\
\hline
\end{tabular}

Sebelum dilakukan uji hipotesis, dilakukan uji prasyarat yaitu uji normalitas dan uji homogenitas. Uji normalitas dilakukan menggunakan uji Kolmogorov- smirnov dengan bantuan program SPSS 21.0 for windows dengan taraf signifikansi $5 \%$ diperoleh nilai signifikansi 0,01 untuk kelas eksperimen dan 0,03 untuk kelas kontrol. Dengan demikian dapat disimpulkan bahwa data hasil belajar siswa tidak terdistribusi normal. Selanjutnya dilakukan uji homogenitas dengan bantuan program SPSS 21.0 for windows menggunakan Test of Homogenity of Variance (Levene) diperoleh nilai signifikansi 0,29 ( > 0,05). Dapat disimpulkan bahwa data hasil belajar siswa kelas kontrol dan kelas eksperimen memiliki varian yang sama/ homogen.

\section{Uji Hipotesis}

1. Uji Hipotesis tentang Ada Tidaknya Pengaruh Penggunaan Media Audio Visual dalam Strategi Problem Posing terhadap Motivasi Belajar Siswa

Berdasarkan hasil uji prasyarat analisis motivasi belajar siswa diketahui bahwa data motivasi belajar kelas kontrol dan kelas eksperimen tidak terdistribusi normal dan memiliki varian yang sama (homogen). Dengan demikian uji hipotesis dilakukan dengan teknik analisis non- parametrik yaitu Uji U-Mann Whitney. Hipotesis yang diuji adalah sebagai berikut.

$\mathrm{H}_{0}$ : tidak terdapat perbedaan motivasi belajar antara siswa yang dibelajarkan menggunakan media audio visual dengan strategi pembelajaran Problem Posing dengan siswa yang dibelajarkan dengan strategi pembelajaran Problem Posing tanpa menggunakan media audio visual pada materi larutan penyangga.

Ringkasan hasil Uji Mann Whitney motivasi belajar siswa yang diperoleh disajikan dalam Tabel 6.

Tabel 6. Ringkasan Hasil Uji Mann Whitney Motivasi Belajar Siswa

\begin{tabular}{ccccc}
\hline \multirow{2}{*}{ Variabel } & \multicolumn{2}{c}{ Rata-rata } & Uji Mann Whitney & \multirow{2}{*}{ Kesimpulan Analisis } \\
\cline { 2 - 4 } & Eksperimen & Kontrol & Signifikansi & \\
\hline Motivasi belajar & 79,84 & 72,63 & 0,023 & Ada perbedaan \\
\hline
\end{tabular}


Berdasarkan data hasil uji Mann Whitney pada Tabel 6 diperoleh nilai signifikansi sebesar 0,02. Berdasarkan data tersebut signifikansi $<0,05(0,02<0,05)$ berarti $\mathrm{H}_{0}$ ditolak dan $\mathrm{H}_{1}$ diterima. Dengan demikian dapat disimpulkan bahwa ada perbedaan motivasi belajar antara siswa yang dibelajarkan menggunakan media audio visual dalam strategi pembelajaran Problem Posing dengan siswa yang dibelajarkan dengan strategi pembelajaran Problem Posing tanpa menggunakan media audio visual pada materi larutan penyangga.

\section{Uji Hipotesis tentang Ada Tidaknya Pengaruh Penggunaan Media Audio Visual dalam Strategi Problem Posing terhadap Hasil Belajar Siswa}

Berdasarkan hasil uji prasyarat hasil belajar siswa diketahui bahwa data hasil belajar kelas kontrol dan kelas eksperimen tidak terdistribusi secara normal dan memiliki varian yang sama (homogen). Dengan demikian uji hipotesis dilakukan dengan teknik analisis non-parametrik menggunakan Uji U-Mann Whitney dengan bantuan program SPSS 21.0 for windows. Hipotesis yang diajukan dalam penelitian ini adalah sebagai berikut.

H0 : tidak terdapat perbedaan hasil belajar antara siswa yang dibelajarkan menggunakan media audio visual dengan strategi pembelajaran Problem Posing dengan siswa yang dibelajarkan dengan strategi pembelajaran Problem Posing tanpa menggunakan media audio visual pada materi larutan penyangga. Tabel 7.

Ringkasan hasil Uji Mann Whitney hasil belajar siswa yang diperoleh disajikan dalam

Tabel 7. Ringkasan Hasil Uji Mann Whitney Hasil Belajar Siswa

\begin{tabular}{ccccc}
\hline \multirow{2}{*}{ Variabel } & \multicolumn{2}{c}{ Rata-rata } & Uji Mann Whitney & \multirow{2}{*}{$\begin{array}{c}\text { Kesimpulan } \\
\text { Analisis }\end{array}$} \\
\cline { 2 - 4 } & Eksperimen & Kontrol & Signifikansi & Ada perbedaan \\
\hline Hasil belajar & 74,25 & 58,61 & 0,00 & Ad \\
\hline
\end{tabular}

Berdasarkan data hasil uji Mann Whitney pada Tabel 4.6 diperoleh nilai signifikansi sebesar $0,00(0,00<0,05)$ berarti $\mathrm{H}_{0}$ ditolak dan $\mathrm{H}_{1}$ diterima. Dengan demikian dapat disimpulkan bahwa terdapat perbedaan hasil belajar antara siswa yang dibelajarkan menggunakan media audio visual dalam strategi pembelajaran Problem Posing dengan siswa yang dibelajarkan dengan strategi pembelajaran Problem Posing tanpa menggunakan media audio visual pada materi larutan penyangga.

\section{PEMBAHASAN}

\section{A. Keterlaksanaan Strategi Pembelajaran Problem Posing Menggunakan Media Audio Visual pada Materi Larutan Penyangga}

Data keterlaksanaan proses pembelajaran problem posing menggunakan media audio visual tersaji dalam Tabel 8 . 
Tabel 8. Data Keterlaksanaan Proses Pembelajaran

\begin{tabular}{ccc}
\hline \multirow{2}{*}{ RPP Pertemuan } & \multicolumn{2}{c}{ Keterlaksanaan Pembelajaran } \\
\cline { 2 - 3 } & Kelas Eksperimen & Kelas Kontrol \\
\hline Pertama & $97,00 \%$ & $90,00 \%$ \\
Kedua & $92,00 \%$ & $95,00 \%$ \\
Ketiga & $93,00 \%$ & $94,00 \%$ \\
Rata-rata & $94,00 \%$ & $93,00 \%$ \\
\hline
\end{tabular}

Tabel 8 menunjukkan bahwa rata-rata persentase keterlaksanaan pembelajaran pada kelas eksperimen sebesar 94,00\% dan proses pembelajaran pada kelas kontrol sebesar 93,00\%. Berdasarkan kriteria maka dapat disimpulkan bahwa pada kelas kontrol dan kelas eksperimen proses pembelajaran telah terlaksana dengan sangat baik.

\section{B. Perbedaan Motivasi Belajar Kelas Eksperimen Dan Kelas Kontrol}

Data motivasi belajar siswa diperoleh dari angket yang diberikan setelah semua proses pembelajaran selesai. Setelah dilakukan uji hipotesis diketahui bahwa terdapat perbedaan motivasi belajar antara siswa yang dibelajarkan dengan strategi pembelajaran Problem Posing menggunakan media audio visual dengan siswa yang dibelajarkan menggunakan strategi pembelajaran Problem Posing tanpa menggunakan media audio visual pada materi larutan penyangga.

Berdasarkan Tabel 4 dapat diketahui bahwa siswa yang dibelajarkan dengan strategi Problem Posing menggunakan media audio visual memiliki persentase siswa yang sangat termotivasi sebesar $28,12 \%$ dan persentase siswa yang termotivasi sebesar $71,87 \%$. Tidak ada siswa yang tidak termotivasi dan sangat tidak termotivasi. Siswa yang dibelajarkan dengan strategi Problem Posing tanpa menggunakan media audio visual memiliki persentase siswa yang sangat termotivasi sebesar 48,48\%, persentase siswa yang termotivasi sebesar 33,33\%, dan siswa yang tidak termotivasi sebesar 18,18\%. Tidak ada siswa yang sangat tidak termotivasi. Hal ini menunjukkan bahwa motivasi belajar siswa yang dibelajarkan dengan strategi pembelajaran Problem Posing menggunakan media audio visual persentasenya lebih tinggi jika dibandingkan siswa yang dibelajarkan dengan strategi pembelajaran Problem Posing tanpa menggunakan media audio visual. Indikator motivasi belajar yang dapat diketahui melalui angket adalah: 1) perhatian siswa terhadap pembelajaran yang dilaksanakan; 2) keyakinan dan kepercayaan diri siswa dalam memahami materi pembelajaran; 3) kepuasan siswa terhadap proses pembelajaran dan hasil belajar; dan 4) memahami relevansi materi yang dipelajari dengan materi-materi selanjutnya maupun dengan kehidupan sehari- hari. Perbedaan motivasi belajar lebih lengkap dapat dilihat pada Tabel 9.

Dilihat dari data persentase masing-masing indikator motivasi belajar pada Tabel 4 dapat diketahui bahwa persentase masing-masing indikator motivasi belajar pada kelas eksperimen lebih tinggi daripada persentase indikator motivasi belajar siswa pada kelas kontrol. Dapat disimpulkan bahwa pembelajaran dengan strategi pembelajaran Problem Posing menggunakan media audio visual dapat meningkatkan motivasi belajar siswa.

Perbedaan motivasi belajar siswa pada penelitian ini tidak lepas dari proses pembelajaran yang telah dilakukan. Siswa memahami materi melalui kegiatan mendengar dan melihat materi yang disampaikan melalui media berbasis audio visual 
yang telah dikembangkan oleh Yuniar Wijayanti Wikaton pada tahun 2012. Penggunaan media audio visual pada siswa yang diajarkan dengan strategi pembelajaran Problem Posing juga dapat membuat proses pembelajaran lebih interaktif dan menarik perhatian siswa sehingga menumbuhkan motivasi belajar yang lebih tinggi.

Tabel 9. Persentase Indikator Motivasi Belajar Kelas Eksperimen dan Kelas Kontrol

\begin{tabular}{|c|c|c|c|}
\hline \multirow[t]{2}{*}{ No } & \multirow[t]{2}{*}{ Indikator Motivasi Belajar } & \multicolumn{2}{|c|}{ Persentase } \\
\hline & & Kelas eksperimen & Kelas kontrol \\
\hline \multirow[t]{6}{*}{1} & Perhatian terhadap pembelajaran (Attention) & & \\
\hline & a. Rasa senang & $83,75 \%$ & $76,33 \%$ \\
\hline & b. Perhatian terhadap tugas & $83,67 \%$ & $73,67 \%$ \\
\hline & c. Ketepatan waktu menyelesaikan tugas & $86,00 \%$ & $80,50 \%$ \\
\hline & d. Kehadiran di kelas & $88,50 \%$ & $83,00 \%$ \\
\hline & e. Suasana pembelajaran di kelas & $95,00 \%$ & $85,00 \%$ \\
\hline \multirow[t]{5}{*}{2} & Keyakinan dan percaya diri (Confidence) & & \\
\hline & a. Keyakinan akan materi pembelajaran & $67,00 \%$ & $62,00 \%$ \\
\hline & b. Keyakinan dapat memahami pelajaran & $76,50 \%$ & $68,50 \%$ \\
\hline & c. Cita-cita & $89,00 \%$ & $79,00 \%$ \\
\hline & d. Percaya diri & $76,00 \%$ & $72,00 \%$ \\
\hline \multirow[t]{7}{*}{3} & Kepuasan (Satisfaction) & & \\
\hline & a. Kepuasan terhadap hasil belajar & $70,00 \%$ & $68,00 \%$ \\
\hline & b. Keinginan berprestasi & $95,00 \%$ & $87,00 \%$ \\
\hline & c. Kepuasan setiap mengikuti pembelajaran & $75,00 \%$ & $69,00 \%$ \\
\hline & d. Kepuasan mengerjakan tes & $84,50 \%$ & $73,00 \%$ \\
\hline & e. Kesenangan dalam belajar & $69,50 \%$ & $62,00 \%$ \\
\hline & f. Rasa senang terhadap pujian & $72,00 \%$ & $56,00 \%$ \\
\hline \multirow[t]{4}{*}{4} & Relevansi (Relevance) & & \\
\hline & a. Perumusan tujuan instruksional & $79,00 \%$ & $73,00 \%$ \\
\hline & $\begin{array}{l}\text { b. Manfaat materi yang dipelajari untuk } \\
\text { selanjutnya }\end{array}$ & $76,00 \%$ & $72,00 \%$ \\
\hline & c. Kesempatan berlatih saat pembelajaran & $72,00 \%$ & $60,50 \%$ \\
\hline
\end{tabular}

\section{Perbedaan Hasil Belajar Kelas Eksperimen Dan Kelas Kontrol}

Data hasil belajar siswa diperoleh dari nilai ulangan harian materi larutan penyangga setelah semua materi disampaikan. Setelah dilakukan analisis terhadap data hasil belajar siswa pada kedua kelas diketahui bahwa terdapat perbedaan hasil belajar antara siswa yang dibelajarkan dengan strategi pembelajaran Problem Posing menggunakan media audio visual dengan siswa yang dibelajarkan dengan strategi pembelajaran Problem Posing tanpa menggunakan media audio visual.

Siswa yang dibelajarkan dengan strategi pembelajaran Problem Posing menggunakan media audio visual memiliki hasil belajar yang lebih tinggi $(\mathrm{x}=74,25)$ dibandingkan siswa yang dibelajarkan dengan strategi pembelajaran Problem Posing tanpa menggunakan media audio visual $(\mathrm{x}=58,60)$. Menurut Mulyaningsih (2011) rata-rata hasil belajar kelas eksperimen sebesar 74,25 memenuhi kriteria cukup sedangkan rata-rata hasil belajar kelas eksperimen sebesar 58,60 memenuhi kriteria kurang. 
Perbedaan hasil belajar ini tidak lepas dari pengalaman belajar siswa selama mempelajari materi larutan penyangga. Selama kegiatan pembelajaran berlangsung, siswa mempelajari materi larutan penyangga melalui media audio visual. Setelah itu, pemahaman siswa dicek dengan mengerjakan Lembar Kerja Siswa (LKS) Problem Posing. Siswa yang dibelajarkan dengan strategi pembelajaran Problem Posing menggunakan media audio visual mempunyai nilai LKS yang lebih tinggi daripada siswa yang dibelajarkan dengan strategi pembelajaran Problem Posing tanpa menggunakan media audio visual. Hal itu sebanding dengan hasil belajar siswa yang lebih tinggi pula. Selain itu penggunaan media audio visual dalam pembelajaran dapat meningkatkan motivasi dan semangat siswa untuk belajar dan berprestasi. Perbandingan nilai LKS siswa yang dibelajarkan dengan strategi pembelajaran Problem Posing menggunakan media audio visual dengan siswa yang dibelajarkan dengan strategi pembelajaran Problem Posing tanpa menggunakan media audio visual dapat dilihat pada Tabel 10.

Table 10. Ringkasan Nilai LKS Problem Posing

\begin{tabular}{ccccc}
\hline \multirow{2}{*}{ Kelas } & \multirow{2}{*}{ Pertemuan } & \multicolumn{3}{c}{ Nilai LKS Problem Posing } \\
\cline { 3 - 5 } & & Nilai terendah & Nilai tertinggi & Rata-rata \\
\hline \multirow{2}{*}{ Eksperimen } & I & 28,57 & 92,86 & 72,50 \\
& II & 73,53 & 82,35 & 78,33 \\
\multirow{2}{*}{ Kontrol } & III & 65,00 & 85,00 & 75,50 \\
& I & 42,85 & 85,71 & 62,50 \\
& II & 70,59 & 82,35 & 74,61 \\
& III & 60,00 & 80,00 & 69,50 \\
\hline
\end{tabular}

Bila dilihat dari rata-rata nilai LKS siswa kelas eksperimen $(\mathrm{x}=75,44)$ dari tiga pertemuan yang lebih tinggi dibandingkan dengan rata-rata nilai LKS siswa kelas kontrol ( $\mathrm{x}=68,87$ ) dapat dilihat bahwa bantuan media audio visual berpengaruh terhadap kemampuan pemahaman rata-rata siswa terhadap materi larutan penyangga. Media audio visual sebagai salah satu sumber belajar bagi siswa dan sebagai acuan bagi siswa dalam membentuk soal serta menyelesaikan soal buatan teman terbukti dapat meningkatkan pemahaman siswa dilihat dari rata-rata nilai LKS yang dikerjakan. Belajar dengan menggunakan media audio visual akan memperoleh pemahaman yang lebih baik dan utuh meliputi 3 aspek yaitu makroskopik, mikroskopik, dan simbolik.

Peningkatan hasil belajar siswa yang dibelajarkan dengan bantuan media audio visual juga didukung dengan hasil penelitian yang dilakukan oleh Gul, Kiyani, Chuadhry \& Liaqut pada tahun 2014. Penelitian dilakukan terhadap siswa SMP Kelas 9 di Pakistan mengenai fungsi bantuan media audio visual terhadap kognitif siswa Sekolah Menengah Pertama (SMP) menunjukkan bahwa penggunaan media audio visual meningkatkan hasil pembelajaran daripada menggunakan metode tradisional. Peneliti juga menyarankan kepada guru untuk mengeksplor penggunaan media audio visual dalam mengajar.

Berdasarkan hasil validasi dan didukung oleh hasil penelitian ini maka dapat disimpulkan bahwa media pembelajaran audio visual yang telah dikembangkan oleh Yuniar Wijayanti Wikaton pada materi larutan penyangga telah layak untuk diterapkan dalam proses pembelajaran di kelas dan terbukti dapat meningkatkan hasil belajar siswa. 


\section{KESIMPULAN}

Berdasarkan hasil penelitian yang telah dilakukan, diperoleh kesimpulan sebagai berikut.

1. Ada perbedaan motivasi belajar antara siswa yang dibelajarkan dengan strategi pembelajaran Problem Posing menggunakan media audio visual dengan siswa yang dibelajarkan dengan strategi pembelajaran Problem Posing tanpa menggunakan media audio visual pada materi larutan penyangga. Motivasi belajar siswa yang dibelajarkan dengan strategi pembelajaran Problem Posing menggunakan media berbasis audio visual ( $x=79,84$; kriteria termotivasi) lebih tinggi dari pada siswa yang dibelajarkan dengan strategi pembelajaran Problem Posing tanpa menggunakan media berbasis audio visual $(x=72,63$; kriteria termotivasi).

2. Ada perbedaan hasil belajar antara siswa yang dibelajarkan dengan strategi pembelajaran Problem Posing menggunakan media audio visual dengan siswa yang dibelajarkan dengan strategi pembelajaran Problem Posing tanpa menggunakan media audio visual pada materi larutan penyangga. Hasil belajar siswa yang dibelajarkan dengan strategi pembelajaran Problem Posing menggunakan media audio visual $(x=$ 74,25; kriteria cukup) lebih tinggi dari siswa yang dibelajarkan dengan strategi pembelajaran Problem Posing tanpa menggunakan media berbasis audio visual $(x=$ 58,60; kriteria kurang).

Saran yang dapat diberikan berdasarkan hasil penelitian yang telah dilakukan adalah sebagai berikut.

1. Untuk meningkatkan motivasi belajar dan hasil belajar siswa, guru dapat menggunakan media audio visual pada pembelajaran Problem Posing dalam pembelajaran kimia terutama pada materi larutan penyangga.

\section{DAFTAR RUJUKAN}

Akay, Hayri. \& Boz, Nihat. 2010. The Effect of Problem Posing Oriented Analyses-II Course on the Attitude toward Mathematics and Mathematics Self-Efficacy of Elementary Prospective Mathematics Teachers. Australian Journal of Teacher Education, (Online), 35(1): 6171, (http://ro.ecu.edu.au/cgi/viewcontent.cgi?article=1329\&context=ajte), diakses 25 Agustus 2014.

Amarta, F. S. 2011. Analisis Kesalahan Konsep Materi Larutan Penyangga pada Siswa Kelas XI IPA SMA Negeri 1 Tumpang Tabun Pelajaran 2010/2011. Skripsi tidak diterbitkan. Malang: Fakultas Matematika dan Ilmu Pengetahuan Alam Universitas Negeri Malang.

El Sayed, Reda Abu-Elwan. 2000. Effectiveness Of Problem Posing Strategies On Prospective Mathematics Teacher's Problem Solving Performance. Journal Of Science And Mathematics Education In S.E Asia. 25(1): 58, (http://www.recsam.edu.my/R\&D_Journals/YEAR2002/2002Vol25No1/56-69.pdf), diakses 19 April 2015.

Gul, Shala., Kiyani, Almas., Chuadry, Muhammad Asif., \& Liaqut, Sumaira. 2014. Role of Audio Visual Aids on The Cognition of Students At Secondary Level. International Journal of Innovation and Applied Studies, Innovative Space of Scientific Research Journals, (Online), 9(3): 1147, (http://www.ijias.issr-journals.org/abstract.php?article=IJIAS-14-283-05), diakses 19 April 2015 
Iskandar, M. Srini. 2011. Pendekatan Pembelajaran Sains Berbasis Konstruktivis. Malang: Bayumedia Publishing.

Mulyaningsih, Sri Endang. 2011. Penggunaan Media Gambar Untuk Meningkatkan Kompetensi Menulis Paragraf Persuasi Pada Siswa Kelas X SMA Negeri 1 Pekalongan. Didaktika Jurnal Kependidikan, 11.

Pekdag, Bulent. 2010. Alternative Methods in Learning Chemistry: Learning With Animation, Simulation, Video, and Multimedia. Journal of Turkish Science Education, (Online), 7(2): 112, (http://www.tused.org/internet/tused/archive/v7/i2/text/tusedv7i2a5.pdf) diakses 19 April 2015.

Sagala, Syaiful. 2003. Konsep dan Makna Pembelajaran. Bandung: Alfabeta.

Santrock, John, W. 2009a. Educational Psycology ( $3^{\text {rd }}$ ed, vol 1). (terjemahan oleh Diana Angelica), Jakarta: Salemba Humanika.

Wikaton, Yuniar Wijayanti. 2012. Pengembangan Media Pembelajaran Audio- Visual untuk Materi Larutan Penyangga pada Siswa SMA Kelas XI Semester 2. Skripsi tidak diterbitkan. Malang: Fakultas Matematika dan Ilmu Pengetahuan Alam Universitas Negeri Malang. 